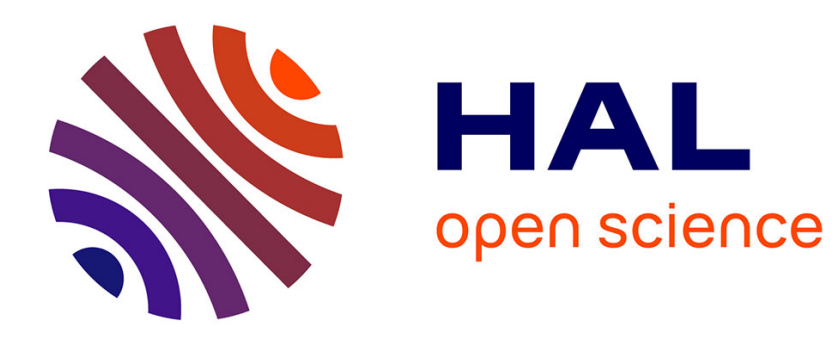

\title{
The Implementation of Participatory Democracy in French Communes
}

Christophe Premat

\section{To cite this version:}

Christophe Premat. The Implementation of Participatory Democracy in French Communes. French Politics, 2009, 7 (1), pp.1-18. 10.1057/fp.2009.5 . halshs-00389314

\section{HAL Id: halshs-00389314 https://shs.hal.science/halshs-00389314}

Submitted on 28 May 2009

HAL is a multi-disciplinary open access archive for the deposit and dissemination of scientific research documents, whether they are published or not. The documents may come from teaching and research institutions in France or abroad, or from public or private research centers.
L'archive ouverte pluridisciplinaire HAL, est destinée au dépôt et à la diffusion de documents scientifiques de niveau recherche, publiés ou non, émanant des établissements d'enseignement et de recherche français ou étrangers, des laboratoires publics ou privés. 


\section{The implementation of participatory democracy in French communes}

Abstract: the purpose of the article is to analyze how participatory democracy has been implemented in French communes. The question of neighbourhood democracy is a norm of political speech as local representatives need to legitimize their role in public space by getting closer to their electors. Does the implementation of participatory tools depend on the ideology and the socialization of the mayors or on the structure of the commune (size, territorial configuration)?

The paper will mainly use a quantitative investigation made on communes above 5 000 inhabitants as well as interviews conducted in specific communes which were known for their participatory culture.

Keywords: participatory democracy, socialization, territorial configuration, size of the commune, local consultations

The topic of participatory democracy was dealt with in the last campaign for presidential elections in France in 2007. The socialist candidate Ségolène Royal adopted it as a strategy for running the election (Sintomer, 2007). She developed the idea of citizen juries in the second TV debate on 24 October 2006 when she was engaged in the primaries of Socialist Party in order to be chosen as the candidate for the election of 2007 (Premat, 2006). This is the first time that participatory democracy was mentioned in the national electoral debate: this fact illustrates the way some representatives see it as a potential resource to renew the image of representative system and strengthen the voter turnout (Kersting, 2005: $33)$.

Participatory democracy includes all tools that allow citizens to interfere with the political process outside elections (Almond, Verba, 1963: 8). Jörgen Westerståh1 distinguished four types of political participation: the electoral participation, the direct participation to decisions thanks to referenda, district councils and local assemblies, the indirect participation through political organizations and potential participation due to the knowledge and interest in political matters (Westerståhl, 1981: 438). The field of participatory democracy fits the second type of political participation. Whereas representative democracy defines all the regular occasions to take part in the choice of representatives, 
direct democracy includes all the mechanisms which interfere with the decisions (referenda, popular initiatives, face-to-face relations) and participatory democracy highlights the deliberative aspect (Fishkin, 1995: 4). In other words, participatory democracy is the name given to all political systems between pure direct democracy (citizens take directly part in main political decisions) and pure representative system (citizens just choose people in charge of public duties). These two extremes work as ideal-types because participatory elements and representative system are mixed in the reality (Budge, 1996: 44). In fact, participatory democracy is composed of a multitude of tools which affect the political process at different stages. For instance, the consensus conferences aim at selecting a panel of citizens who become well-informed of scientific problems (Boy, Donnet-Kamel, Roqueplo, 2000) whereas the district councils focused on the micro-level deliberative aspect. All tools cannot be simply compared as the question of scale is crucial: who is eligible to take part in the process (Weale, 1999: 146)? What for? When and how long? (Falise, 2003: 52-53). Participatory democracy involves specific citizens who help politicians to take a decision on a particular topic (Bourg, Boy 2005: 5).

The topic of participatory democracy has been more and more popular among citizens and representatives in France who regard it as a way of strengthening and legitimizing political decisions thanks to organized discussions. The local level seems to be appropriate to the experimentation of participatory processes. We would like to analyze how participatory democracy has been implemented at local level that means how French communes created specific participatory instruments which involve inhabitants in local affairs. First, we will use macro-level aggregate data on political attitudes of French citizens thanks to the questionnaires of World Values Survey. How do French citizens perceive their relation to political participation? We will compare the attitude of citizens with the series of laws concerning participatory democracy from the nineties on: did the representatives try to adapt 
to the shift of values of the citizens? Second, we will use a database made on participatory tools in French communes above 5000 inhabitants in 2006 in order to appreciate the influence of political context and the territorial configuration in the implementation of participatory tools. Is there a correlation between the size of the commune, the territorial configuration, the socialization of local representatives and the implementation of participatory democracy? These data will be completed by half-directive interviews made with local representatives of communes that developed a specific participatory culture.

The research design is inspired by the configurative comparative approach developed by Charles C. Ragin (Ragin, 2004) which combines quantitative and qualitative studies. The quantitative overview is important in order to define a general trend and find out specific cases. We extracted the cases of communes which developed a participatory culture by promoting a panel of instruments and proceeded different interviews with political actors involved in participatory democracy. The final goal is to study the way local politicians implement participatory instruments (Unger, 1998).

\section{Political attitudes and values in France}

The political attitude of citizens can be measured through specific data extracted from World Values Survey. We are interested in analyzing non-conventional participation that means specific mobilizations outside traditional organizations such as political parties or trade-unions. Conventional participation can be expressed through different political acts such as signing up petitions, taking part in demonstrations and boycotts, occupying factories' buildings, organizing strikes. These specific acts reveal citizen mistrust towards political institutions: this is why we deal with values of participation when we consider this specific repertoire. Pippa Norris noticed that the non-conventional participation has become a norm in most of the western societies (Norris, 1999: 263). Based on an analysis of World Values 
Surveys (WVS) data in 44 countries, she noticed that the more citizens got involved in political matters, the less they claimed any political belonging and the less they had trust in institutions. In the data concerning France in the fourth wave of $\mathrm{WVS}^{1}, 34 \%$ of the answerers declared that they took part in a peaceful demonstrations, $13 \%$ said that they had boycotted a product in the past; $11.2 \%$ took part in an unofficial strike and $8.3 \%$ organized a sit-in in a factory to support a protest. These answers show that the non-conventional participation has been more and more important in France. If we compare these data with other countries such as Germany ${ }^{2}$, then we see the difference in the modalities of participation as only $2 \%$ of them took part in unofficial strikes and $1.3 \%$ occupied factories' buildings. The repertoire of protest is stronger in France as there is a prevailing mistrust in political institutions.

The importance of non-conventional participation (Taniguchi, 2006: 416) illustrates the shift of values among French citizens. In the WVS, a special indicator was created to study the post-materialistic trend (care for environment and quality of life, mistrust in political authority, promotion of other ways of engagement in politics). The emphasis on new ways of taking part in politics is a characteristic of post-materialistic values. When we look at the results presented in table 1 , we observe that around $20 \%$ of the respondents share postmaterialistic values and $27 \%$ of them materialistic values. The majority of them shares mixed values, which means that materialistic and post-materialistic attitudes coexist and vary with the topic (Inglehart, Baker 2000). Some respondents wish to have more participation in the political process while they support a clear authority in the political system. Those attitudes can reflect conflict of values: as a matter of fact, they show that the shift of values is an ongoing process in France and that the citizens are critical about the political institutions. The

\footnotetext{
${ }^{1}$ European Values Study Group and World Values Survey Association. EUROPEAN AND WORLD VALUES SURVEYS FOUR-WAVE INTEGRATED DATA FILE, 1981-2004, v. 20060423, 2006. Aggregate File Producers: Análisis Sociológicos Económicos y Políticos (ASEP) and JD Systems (JDS), Madrid, Espagne/Tilburg University, Tilburg, Pays-Bas. Data Files Suppliers: ASEP and JDS, Zentralarchiv für Empirische Sozialforschung (ZA), Cologne. Aggregate File Distributors: ASEP, JDS and ZA. The total number of respondents is 3680 for France.

${ }^{2}$ The number of answerers is 7268 for Germany.
} 
French local elites are aware of this evolution and adapted themselves to it by allowing citizens to take part in the elaboration of public policies. This is how we can understand the institutionalization of participatory tools since 1992 in France.

\section{The context of participatory democracy}

A series of laws has been voted in France since 1992. A law enacted on 6 February 1992, authorised the consultation of "inhabitants" for a limited number of topics. Many extramunicipal commissions were introduced and the participation of inhabitants was recommended. The concept of consultative popular initiative was introduced for the first time on 4 February 1995. One fifth of the electors can request the organization of a local consultation. District councils (conseils de quartier) were created and the law of 27 February 2002 made them compulsory for cities having more than 80000 inhabitants. Recently, the second Act of Decentralization of 1 August 2003 recognized the binding local referendum and dealt with the idea of citizen participation. The table 2 reports the use of the expression "participatory democracy" in the parliamentarian debates since 1986 . We observe that the topic was deeply discussed between 2001 and 2003, especially because of the law of 27 February 2002 and the second Act of Decentralization. The topic is nowadays prevailing in local politics and this is why we focused on the degree of the implementation of participatory democracy in French communes. Participatory democracy makes politics at local level more complex as mayors have to adjust their agenda to the problems of inhabitants. There is a “'built-in-tension'" between output- and input-orientation: intentions to enhance local government efficiency might create problems for democratic inclusiveness and vice-versa" (Steyvers, Pilet, Reynaert, Delwit, 2005: 24). Participatory tools have been created in France to make citizens take part in the definition of adequate local policies. 
Between 1992 and 2003, different participatory tools have been created such as local consultative council of wise men (conseils des aînés), children local councils (conseils municipaux d'enfants), young councils (conseils de jeunes), district councils (conseils de quartier), councils of foreign communities (conseils des communautés étrangères), urban planning sessions (ateliers d'habitants) and diverse consultative councils. There are a lot of different labels for participatory tools as the association for social and local democracy (ADELS) counted down 184 different names for participatory instruments ${ }^{3}$. In a survey made on 140 directors of communication of French communes above 10000 inhabitants, a question referred to the implementation of participatory democracy: $26 \%$ of them declared that they had young councils in their communes, $20 \%$ councils of wise men and $5 \%$ councils of foreign communities ${ }^{4}$. Political elites use participatory democracy as a means to create a feeling of local community which can be useful to legitimize their power and renew their image among electors. The quantitative analysis on participatory tools gives an accurate idea of the new participatory policies promoted by French mayors.

\section{An empirical study}

The present study focuses on the implementation of participatory democracy in 2006 in the 1881 communes which have more than 5000 inhabitants. In order to build the sample, we referred to the website of Profession politique, which is an exhaustive website edited by the Société d'édition publique (SEP), a press group specialized in information about public life. Profession politique is a weekly magazine ${ }^{5}$ and presents a database on French and European political life. All the data on the French political personnel are regularly updated.

\footnotetext{
${ }^{3}$ Territoires, $\mathrm{n}^{\circ} 441$, October 2003.

${ }^{4}$ Survey made by the firm Opinionway between 1 and 13 November on 140 directors of communications of communes above 10000 inhabitants. The survey was made by CAWI System (Computer Assisted Web Interview). There are 921 communes above 10000 inhabitants in France.

5 http://www.professionpolitique.info
} 
This database includes different sociological and political information on mayors from municipalities with more than 2500 inhabitants and is based on the census made by the INSEE in 2004. The table 3 deals with the size of the French communes above 5000 inhabitants: around $87 \%$ of the communes of the sample have between 5000 and 30000 inhabitants. The table 4 gives the political belonging of the mayors of all these communes: $19 \%$ of mayors do not claim any political belonging, they won their mandate without referring to any political party; 29\% of the communes between 5000 and 10000 inhabitants have such mayors. The bigger the commune is, the more the mayors are engaged politically. We added to the main conservative party (UMP) the mayors from the right wing who are not members of any political party and to the Socialist party the mayors from the left wing without any political membership. We observe in 2006 a balance between the right wing and the left wing (stability of the cleavage right / left) for the entire sample.

\section{The territorial configuration}

The territorial configuration (Elias, 1991: 154-61) includes the size of the city and its institutional environment (population density, inter-municipal structure). In the field of political science, Robert A. Dahl initiated a work on the topic of size and democracy in the seventies (Dahl, Tufte, 1974). These investigations are still pursued with the works of Larsen (Larsen, 2002) and Le Roy (Le Roy, 1995). Robert A. Dahl points out the difficult relation between participation and the size of units: "for most citizens, participation in very large units becomes minimal and in very small units it becomes trivial. At the extremes, citizens may participate in a vast range of complex and crucial decisions by the single act of casting a ballot; or else they have almost unlimited opportunities to participate in decisions over matters of no importance. At the one extreme, then, the people vote but they do not rule; at the other, they rule - but they have nothing to rule over" (Dahl, 1971: 97). He establishes an explicative model that we can sum up in an antagonistic relation between the control of 
political decisions by the citizens and the efficiency of the public policies. Those two sides vary with the size of political systems. The higher the size increases, the higher the efficiency is but the poorer the citizen participation gets. This size effect is not significant because of the size of the country but because of the distribution of units inside the country (Dahl, Tufte, 1974: 65). If both authors included in their study other factors as political culture, we mainly tested empirically the influence of size by applying it to the French municipalities of more than 5000 inhabitants.

There might be a relation between the size of the commune, the identity of the commune in its environment and the implementation of participatory democracy. The size of the commune and the territory configuration are the two main keys studied in order to observe how this implementation is made. In his work on local system, Albert Mabileau proposed a typology of four models of cities (Mabileau, 1994) that we took in order to elaborate our indicator of urban stratification. In France, $90 \%$ of the communes have less than 2000 inhabitants; as a matter of fact, most of the communes are rural, but this criterion does not take the question of configuration into account. Two communes of the same size can have opposite configurations. This is why the concept of territorial configuration is the most appropriate tool in our investigation.

The mayoral leader is seen in interdependency with his communal environment which is composed of his own political and administrative staff, the communal society and the institutional environment (the type of intercommunalite and the relation of the commune to this structure). In other words, the mayors might choose to implement participatory democracy tools in order to strengthen their leadership on the local territory. We also assume that there is a certain stratum of low-sized and middle-sized cities which specifically implement participatory democracy tools. Those political leaders are more willing than the others to implement them. In some metropolitan areas, the implementation of participatory 
tools will not cause the transformation of political order (Jouve, 2005: 336) as it could do in smaller cities. In the seventies, Robert A. Dahl and Edward R. Tufte refused to find out an optimum size for political participation. "Can we say, then, that there is any optimum size for a political system? In our view, the answer is clearly no. Different problems require political units of different size" (Dahl, Tufte, 1974: 135). This negative statement answers to the second of their three main questions in their research: "more specifically, is 'democracy' related in any way to size? How large should a political system be in order to facilitate rational control by its citizens? What are the comparative advantages and disadvantages enjoyed by political systems of different sizes?" (Dahl, Tufte, 1974: 1). They established a link between the size and the two elements of a democratic system, on the one hand the citizen participation and the feeling of influencing the political process (sense effectiveness) and on the other hand the capacity of the system to answer efficiently to the social demand and solve the complex problems of society. If participation is trivial in small urban units, the big units are more efficient to emit the adequate public policies even though the citizens do not have so many occasions to interfere in the decisions outside the vote. In the current research, the goal is to know whether there is an optimal size of cities which implement participatory democracy.

\section{The socialization of mayors}

The second hypothesis points out the socialization of mayors. There might be a relation between the date of entrance in local politics and the implementation of participatory democracy. The new generation coming from the associative and political world (Mabileau, 2002: 142) might be more willing to use this resource. The local notables, who are deeply rooted in the political system and who have an ancient experience of the mechanism of local politics, are socialized in an elitist political culture which refuses any delegation of power. The cumul des mandats could reinforce a conception of representative democracy. This is 
why those mayors would not implement those kinds of tools (Marrel, 2004: 122-28). The more functions the mayor cumulates, the more monopole he has and the less predisposed to implement participatory instruments. This assumption needs to be tested as we may say the contrary: the more a mayor cumulates, the more he needs to justify his mandate in front of his electors and the more he might implement participatory tools. The mayors who cumulate can use participatory tools as a way of legitimizing their local power while they have different political tasks.

\section{Data and variables}

To test the hypotheses, we used two sets of indicators, the ones related to the dependent variable (the implementation of participatory tools) and the others that make up the independent variables (socio-political indicators about mayors and the structure of the commune).

\section{Dependent variable: the implementation of participatory democracy}

There are many participatory tools that French mayors implemented. We collected the data from the presentation of these tools through the website of every commune above 5000 inhabitants. This variable is ordinal and equals 0 if there is no participatory tool, 1 for one participatory tool and $\mathrm{n}$ for $\mathrm{n}$ instruments. In order to strengthen the indicator on the participatory democracy, we added an associated indicator which is the local consultation. In France, the local consultation was introduced in the law of 6 February 1992 before the law of 1 August 2003 recognized the decisive local referendum when $50 \%$ of the local population takes part in the vote. There have been 102 communes which have been holding at least a consultation since 1992. Almost all the local votes outside elections are consultative: the mayors, who control this instrument, want to make people deliberate on a question. At the same time, they increase their legitimacy (Paoletti, 1997: 234-235). This is why we took local 
consultations as another way of promoting a participatory strategy. The question is to see whether in those communes, the local consultation was used for itself or in connection with other participatory instruments.

\section{Independent variables}

In order to make up the indicator on the size of communes, we distinguished six levels (see table 3). We started from the typology made by Albert Mabileau with the four levels, the big cities, the métropoles d'équilibre, the middle-sized cities and the small cities. In order to be exhaustive, we added two scales to this typology. Then, we built some indicators on the territorial configuration to study their effects on the implementation on participatory democracy. The first one is about rural life, which is defined by three traditional axes according to Jean-Claude Bontron: economical (agricultural activities), sociological (values based on family and the attachment to the farm) and demographical (weak density of population) (Bontron, 2005). The decline of rural societies is explained by the diffusion of an urban life standard and the decrease of rural families in the countryside: there is only the demographic factor which can be taken into account for the difference between urban and rural areas. As a matter of fact, according to the figures from the census of INSEE (French national independent statistics) made in 1999 , we created a variable which measures the density of the district where the commune is located. In order to test the impact of the intermunicipal structures, we established an ordinal variable from the smallest structure to the biggest one: for the communes without any cooperation, the variable scores 0 , then 1 is for the integration in a communauté de communes, 2 in a communauté d'agglomération, 3 in a communauté urbaine or a syndicat d'agglomération nouvelle: 247 communes are not integrated in an inter-municipal structure (13.2\%), 687 communes belong to a communauté de communes (36.5\%), 754 to a communauté d'agglomération (40.1\%) and 192 to the third category $(10.2 \%)$. 
For the indicators testing the impact of socialization of the mayors on the implementation of participatory democracy, we included the age with the birth date of the mayors, the date of their first mandate as mayors and then the first time they had a responsibility in the field of local politics (member of local council, regional counsellor, member of the executive of the department). To test the relation between the cumul des mandats and the implementation of participatory democracy, we created a variable whose goal is only to measure the vertical cumul (other mandates) and not the horizontal ones (other professions). We only took elective mandates and positions of president or vice-president of inter-municipal structures into account as these last functions have been really important (Marrel, 2004: 128) in the reorganization of cumulative strategies since the law on cumul des mandats of 2000. It is not the type of mandate which is important but the cumulative strategy.

\section{Empirical results}

The hypotheses are tested through a linear regression with robust standard errors presented in table 5. First, there is a correlation between the size and the implementation of participatory democracy. With a significant Beta coefficient of 0.29 , it is even the most explicative factor. Indeed, because we excluded rural communes from our sample, we should have found a negative correlation between the implementation of participatory democracy and the size of the communes. This is due to the resources of the communes: the correlation indicates that there is a systematic use of participatory instruments when the commune has more resources, even if the commune is not compelled to develop the participatory instruments. This model shows the diffusion of the participatory norm on the whole territory which is mainly used as a way of legitimizing the work of the representatives. The bigger the commune is, the more it focuses on participatory democracy as a way of getting closer to the electors. 
The increasing tendency to implement participatory elements shows that the link between the size and democracy is not negatively correlated. The correlation confirms that there is no specific size where the efficiency of democracy is balanced by its inclusiveness. If the bigger cities do have the best system capacity, the low-sized cities do not have the monopole of citizen efficiency, as Robert A. Dahl and Edward R. Tufte perceived it thirty years ago: "no single type or size of unit is optimal for achieving the twin goals of citizen effectiveness and system capacity. For in the present world, and even more surely in the future, democratic goals conflict, and no single unit or kind of unit can best serve these goals" (Dahl, Tufte, 1974: 138). The other explanation comes from the structure of big cities: local democracy exists in differents areas such as the arrondissements in Paris. We conducted interviews in different city halls of arrondissements (mairies d'arrondissement) on participatory tools which were implemented. Local democracy is more complex and the units can be fragmented when the commune is quite big. In Paris, local democracy was all the more possible in these arrondissements as the political affiliation of the mayor and certain mayors of arrondissements was not the same ${ }^{6}$. As a matter of fact, participatory democracy is a resource which is at stake in the electoral competition.

The second important explicative factor is the type of inter-municipal structure. The beta coefficient $(0.09)$ is not as high as the one of the size but is above all the other variables. This is to be explained by the fact that the commune does not loose its identity inside a bigger complex. The participatory democracy is then a major resource to build this identity. This result is reinforced by the proximity with Paris: when a commune belongs to the suburb of Paris, it tends to implement participatory democracy in order to strengthen local life and the relations between citizens and representatives. We could verify this fact by conducting specific interviews in communes near Paris which were engaged in the implementation of

\footnotetext{
${ }^{6}$ Interview conducted with Guillaume Métayer, administrative director of the $19^{\text {th }}$ arrondissement (4 June 2004) and Cyril Egner, green party member and vice-mayor of the $3^{\text {rd }}$ arrondissement (5 March 2004).
} 
participatory democracy such as Arcueil, a commune of around 20000 inhabitants in the south part of Paris. The vice-mayor of Arcueil explained us in an interview how participatory democracy was implemented in the commune: "there are thousand ways of taking part in local life in Arcueil. The district councils (conseils de quartier) evolved, we have more and more autonomy; the inhabitants begin to administrate themselves these councils and their budget. Since 1995 and 1996, some members of the local council (conseil municipal) have been appointed to these district councils in order to transmit the summary of these citizen assemblies to the local council. The agenda of these district councils is prepared both by the selected representatives (élus référents) and the citizens [...]. As far as the local council is concerned, we propose different ways of associating inhabitants to the political decisions which affect their environment. [...] In 1997, we created the council budgets; the inhabitants decide how they use this money"7. In this interview, we perceived that the participatory democracy was seen as a top-down process which aimed at stimulating the citizen commitment. It implies the definition of specific instruments and rules in order to be efficient. Participatory democracy is defined as a method of local governance ${ }^{8}$ : the closer the representatives get to the problems of citizens, the more efficient they are in the selection of appropriate local policies.

The sociological variables have a weaker coefficient of significance than the variables of territorial configuration and size. Their explicative role is thus secondary but still gives some important information. There is no correlation between the cumul of mandates and the implementation of participatory democracy: $72 \%$ of the mayors who do not practise the cumul implemented participatory tools against $77 \%$ of the ones who have several mandates. The mayors tend to use participatory tools as a strategy which corrects the image of distant

\footnotetext{
${ }^{7}$ Interview conducted with Anne Buyck, vice-mayor of Arcueil (16 December 2003).

${ }^{8}$ In an interview conducted in the commune of Lanester (Bretagne, 23000 inhabitants), the director of communication dealt with the "participatory philosophy" that the mayor developed for the commune. Interview conducted in Lanester on 13 September 2006.
} 
politicians. On a survey conducted on European mayors of communes above 10000 inhabitants, 188 French mayors were interviewed (20\% of the French communes above 10 000 inhabitants): 27 mayors have been in office in more than five years. On the whole, they approve participatory tools such as neighbourhood panels $(76.3 \%)^{9}$. The political experience is not necessarily opposed to the implementation of participatory democracy.

When we look at the relation between the first time the mayors were elected and the implementation of participatory democracy, we notice that the election of 1977 was the first step in this direction: $77 \%$ of the mayors elected in 1977 and who still govern, introduced participatory tools (Wargny, 1978), 71\% of the ones elected in 1983 and $70 \%$ of the ones elected the first time in 1989. The 1977 election was characterized by the entry of leftist mayors who dealt with the ideas of participatory democracy; $77 \%$ of the mayors elected in 2001 implemented those tools. The duration of the mandate (cumul in time) is not necessarily contradictory to the implementation of participatory tools. On the contrary, mayors who wish to be elected again, create participatory tools to renew their image. The age of the mayors does not have any influence on the implementation of participatory democracy. In fact, the question of political generation is more important in the implementation of participatory democracy. The mayors who came to power before 1977 are less interested in the promotion of these tools.

The political cleavage does not have any impact on the implementation of participatory democracy as it has become a norm shared by different political parties with a variable intensity. The table 6 shows that all the main political trends are affected in the same proportion by the participatory norm. Participatory democracy is not a discriminating topic at local level in France whereas the left-wing parties are more willing to promote it at national

\footnotetext{
${ }^{9}$ Database SSD 0822 «The European mayor - Political leaders in the changing context of local democracy », Henry Bäck, School of Public Administration, Göteborg University.
} 
level. The difference is in the depth of the participatory reforms conducted at local level: some communes implemented several tools which complete each other. In Arcueil, the preparation of the local consultation of 5 December 1999 on the future of the city was possible because of the connection between different participatory tools: "we decided to hold a referendum on an important issue in local life which is the restructuration of the centre of the city. To prepare it, we organized different debates and we used the district councils as deliberative arenas on the way we should restructure the centre" ${ }^{\prime 10}$. The participatory strategy consists in combining tools so that the citizens can take part in the local political debate on the future of the city.

The configurative comparative approach was used in order to investigate the communes that developed several participatory tools and held local referenda. In these communes, the participatory strategy depended on the will and personality of the mayor like Mons-en-Baroeul in the suburb of Lille (29 000 inhabitants). This commune is the most participatory one in France: four local referenda have been held since 1977, a council of foreigners was created in 1987 as well as other participatory tools. Marc Wolf was the mayor of the commune between 1977 and 2001; he was a member of the Socialist Party and believed in the ideas of self-government. "The left-wing was aware of the importance of the municipal action not only to prepare its access to the government but in itself, in the making of a socialist project based on self-organization" (Wolf, Osselin, 1979: 10). Marc Wolf devoted himself to the implementation of participatory democracy: he decided to hold referenda on local taxes (these referenda were not legal) and let citizens choose the type of local policies that they wanted to have. As the former vice-mayor of Marc Wolf told us, "the referendum system is not easy and not mooted in the French political system. Some citizens prefer to let representatives act instead of making choices. The personality of the former

\footnotetext{
${ }^{10}$ Interview of the vice-mayor of Arcueil, Anne-Marie Buyck, 16 December 2003.
} 
mayor was contested: some people reproached him to be too rigid, but he had an authentic political engagement [...]. As far as I am concerned, Marc Wolf embodies another way of doing politics" $"$. The implementation of participatory tool is linked to the personality of the mayor and its participatory ideology, it is not a bottom-up process.

The organization of local consultations is another way of implementing participatory democracy but unlike the other tools, local consultations are not regular. We notice that 102 mayors held a local referendum between 1992 and 2006 (six communes have held two consultations since 1992 and two communes have known four consultations). Most of them are not binding even though the law opens both possibilities (Premat, 2005: 204). Out of these 102 communes, 88 had implemented participatory tools which underlines the connection between local consultations and participatory tools. Local consultation is seen as one of the instruments which can enlarge the participatory repertoire. According to the survey conducted on European mayors, $80 \%$ of French mayors perceived the local referendum as an appropriate tool of communication between the local leaders and the population ${ }^{12}$. In reality, they used it almost in a consultative way: there have been no binding referenda held in French communes above 10000 inhabitants since the Law of 1 August 2003. In one of the interviews made in Arcueil, a vice-mayor deplored the ambiguous notion of citizen involvement: "We have to go further in the implementation of participatory democracy. We have to associate citizens to the local decisions, it is an openness to the political decision. Only the representatives decide, we do not mix types of governance. We have to make citizens understand that they can influence the decisions, but they do not decide instead of the politicians. We are not enough accurate when we talk to people. We let them believe that democracy is participatory, but we are not sure that the tool will create participation. We can

\footnotetext{
${ }^{11}$ Interview made in Mons-en-Baroeul on 3 December 2005.

${ }^{12}$ Database SSD 0822 « The European mayor - Political leaders in the changing context of local democracy », Henry Bäck, School of Public Administration, Göteborg University.
} 
be wrong if there is no participation [...]. The participatory democracy is under the control of the representative system"13. This is why the implementation of participatory tools is not really deep in France: only consultative tools are promoted in order to control the citizen participation. French local representatives share the republican ideology and do not believe in the real empowerment of citizens (Genieys, 2005).

In a nutshell, the territorial configuration and the size highlight the communicative policies of mayoral leaders in terms of participatory democracy much more than the political career of those leaders. The question of scales and the location of the commune are determining variables in the implementation of participatory democracy which legitimizes the work and the visibility of local leaders. Paradoxically, participatory democracy is not a property of low-sized communes. The big cities use resources in order to implement participatory democracy. Surprisingly, the cumul does not have any influence on the use of participatory implementation. We thought that some local leaders who would have different mandates could have created participatory tools in order to compensate their busy schedule and difficult availability. The mayors also tend to implement participatory policies when their commune belongs to a big inter-municipal structure. There is a relation between territorial configuration and democracy and not only between size and democracy. The administrative environment of the commune has an influence in the implementation of participatory democracy.

Last but not least, the local consultation is a convenient participatory tool as the mayors control it entirely: at the end of 2005 no decisional referendum was organized (Koebel, 2006: 101). Local consultations are like surveys that mayors use to know the

\footnotetext{
${ }^{13}$ Interview conducted with Denis Weisser on 14 December 2003, socialist vice-mayor of Arcueil.
} 
opinion of the citizens. They are mainly used by mayors who implemented participatory tools. On the whole, French local representatives adapted to the participatory norm by implementing tools which are merely consultative. They control the participatory process which shows that participatory democracy reveals the transformation of the representative system: the politicians are more responsive but do not share the main decisions with citizens. The other point is that participatory democracy is a gadget for the mayors who legitimize their local power. The fragmentation of local powers (36 000 communes, 26 regions, 100 départements) is a weakness of the French administrative system. The inter-municipal bodies are a response to the effectiveness of local policies but they are not visible for the citizens (Kerrouche, 2008: 124). The surveys made on citizen values revealed that the citizens were more and more critical towards political institutions; the implementation of consultative tools might not satisfy their wishes to take part in the selection of adequate of public policies.

*Our acknowledgments go to Niall McCourt for his review of the article.

Table 1: Principal values of French citizens

\begin{tabular}{|l|l|l|l|l|}
\hline \multicolumn{1}{|l|}{ Index $\left(^{*}\right)$} & Materialistic values & Mixed values & $\begin{array}{l}\text { Post-Materialistic } \\
\text { values }\end{array}$ & Total \\
\hline France & $1000 \quad$ Source: World Values Survey, Fourth vague ${ }^{14}$ & 3680 \\
\hline
\end{tabular}

\footnotetext{
${ }^{14}$ European Values Study Group and World Values Survey Association. EUROPEAN AND WORLD VALUES SURVEYS FOUR-WAVE INTEGRATED DATA FILE, 1981-2004, v. 20060423, 2006. Aggregate File Producers: Análisis Sociológicos Económicos y Políticos (ASEP) and JD Systems (JDS), Madrid, Espagne/Tilburg University, Tilburg, Pays-Bas. Data Files Suppliers: ASEP and JDS, Zentralarchiv für Empirische Sozialforschung (ZA), Cologne. Aggregate File Distributors: ASEP, JDS and ZA.
} 
Table 2: Apparition of the expression "participatory democracy" in French parliamentarian debates since 1986

\begin{tabular}{|c|c|c|c|}
\hline & \multicolumn{2}{|l|}{ Senate } & \multirow{2}{*}{$\begin{array}{l}\text { National Assembly } \\
\text { Parliamentary discussions }\end{array}$} \\
\hline Year & Bills and Laws & 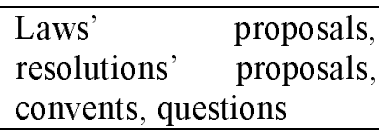 & \\
\hline 2006 & 24 & 4 & 0 \\
\hline 2005 & 25 & 2 & 2 \\
\hline 2004 & 10 & 0 & 7 \\
\hline 2003 & 13 & 0 & 117 \\
\hline 2002 & 6 & 2 & 52 \\
\hline 2001 & 4 & 1 & 127 \\
\hline 2000 & 0 & 1 & 0 \\
\hline 1995-1999 & 2 & 0 & 11 \\
\hline 1986-1994 & 0 & 0 & 0 \\
\hline Total 1986-2006 & 84 & 10 & 316 \\
\hline
\end{tabular}

Source: analysis of the debates thanks to the websites of the Senate and the French Assembly

Table 3: The size of the French communes above 5000 inhabitants

\begin{tabular}{|l|l|l|}
\hline Size of the commune & Number of communes & Proportion \\
\hline $\begin{array}{l}\text { Between } 5000 \text { and } 10000 \\
\text { inhabitants }\end{array}$ & 960 & $51 \%$ \\
\hline Between 10000 and 30000 & 666 & $36 \%$ \\
\hline Between 30000 and 50000 & 137 & $\mathbf{7 \%}$ \\
\hline Between 50 000 and 100000 & 78 & $4 \%$ \\
\hline Between 100000 and 200 000 & 29 & $1.5 \%$ \\
\hline Above 200 000 & 11 & $0.5 \%$ \\
\hline
\end{tabular}

Source: Database 2006, IEP Bordeaux (in cooperation with Julien Dewoghélaëre)

Table 4: The political belonging of mayors from French communes above 5000 inhabitants in 2006

\begin{tabular}{|l|l|l|}
\hline Political affiliation & Number of mayors & Proportion \\
\hline $\begin{array}{l}\text { Without claiming any political } \\
\text { belonging }\end{array}$ & 355 & $19 \%$ \\
\hline UMP (conservative party) & 615 & $32.8 \%$ \\
\hline UDF (Liberal Party) & 116 & $6.2 \%$ \\
\hline Far-right Party (FN) & 2 & $0.1 \%$ \\
\hline Communist Party & 145 & $7.8 \%$ \\
\hline Socialist Party & 615 & $32.8 \%$ \\
\hline Green Party & 11 & $0.6 \%$ \\
\hline Local Parties & 14 & $0.7 \%$ \\
\hline Total & 1873 & $100 \%$ \\
\hline
\end{tabular}

Source: Database 2006, IEP Bordeaux (in cooperation with Julien Dewoghélaëre)

Table 5: The explaining factors of the implementation of participatory democracy in French communes

Number of observations $=1491$ 
$\mathrm{F}(10,1480)=22.85$

Prob $>\mathrm{F}=0.0000$

R-squared $=0.1338$

Adj R-squared $=0.1279$

\begin{tabular}{|l|l|l|l|}
\hline Participatory democracy & Coefficient & Standard Error & $\begin{array}{l}\text { Standards coefficients } \\
\text { Beta }\end{array}$ \\
\hline $\begin{array}{l}\text { Several mandates at the } \\
\text { same time }\end{array}$ & -0.024 & 0.032 & -0.019 \\
\hline $\begin{array}{l}\text { Date of first mandate in } \\
\text { local politics }\end{array}$ & 0.002 & 0.004 & 0.02 \\
\hline $\begin{array}{l}\text { Date of first mandate as a } \\
\text { mayor }\end{array}$ & 0.006 & 0.004 & 0.05 \\
\hline $\begin{array}{l}\text { Member of an inter- } \\
\text { municipal body }\end{array}$ & 0.098 & 0.028 & $0.091^{* * *}$ \\
\hline Population density & 0 & 0 & 0.05 \\
\hline $\begin{array}{l}\text { Proximity with Paris } \\
\text { Number of local }\end{array}$ & 0.14 & 0.038 & $0.01 * * *$ \\
\hline $\begin{array}{l}\text { Neferenda since } 92 \\
\text { Cleavage }\end{array}$ & 0.11 & 0.08 & 0.03 \\
\hline Age & 0.04 & 0.03 & 0.04 \\
\hline Size & 0.002 & 0.003 & 0.017 \\
\hline Const. & .27 & .02 & $.29 * * *$ \\
\hline
\end{tabular}

Significance: $\mathrm{p}^{* * *<0.001, \mathrm{p}^{* *}<0.01, \mathrm{p}^{*}<0.05}$

Source: Database 2006, IEP Bordeaux (in cooperation with Julien Dewoghélaëre)

Table 6: Political affiliation and implementation of participatory tools in French communes of more than 5000 inhabitants

\begin{tabular}{|l|l|l|l|l|l|}
\hline Degree of implementation & $\begin{array}{l}\text { Without any } \\
\text { political } \\
\text { affiliation }\end{array}$ & UMP & PS & PCF & UDF \\
\hline One participatory tool & 199 & 352 & 331 & 66 & 62 \\
\hline Two participatory tools & 44 & 84 & 86 & 17 & 19 \\
\hline Three participatory tools & 7 & 28 & 38 & 8 & 5 \\
\hline Four participatory tools & 7 & 11 & 22 & 12 & 4 \\
\hline $\begin{array}{l}\text { Proportion of mayors } \\
\text { implementing participatory } \\
\text { tools }\end{array}$ & $72.4 \%$ & $77 \%$ & $77.6 \%$ & $71 \%$ & $71.4 \%$ \\
\hline
\end{tabular}

Source: Database 2006, IEP Bordeaux (in cooperation with Julien Dewoghélaëre)

\section{References}

-Almond G. S., Verba S. (1963) The Civic Culture: Political Attitudes and Democracy in Five Nations. Princeton: Princeton University Press.

-Bäck, H., Heinelt, H., Magnier, A. (eds.) (2006) The European Mayor, Political Leaders in the Changing Context of Local Democracy. Wiesbaden: Urban and Regional Research International.

-Bontron, J.-C. (2005) 'L'irrésistible élan de 1'intercommunalité' in: L'état de la France, édition 2005-2006. Paris : La Découverte. 
-Bourg, Dominique, Boy, Daniel (2005) Conférences de citoyens, mode d'emploi. Paris: Charles Léopold Mayer.

-Boy, D., Donnet-Kamel, D., Roqueplo, P. (2000) 'Un exemple de démocratie participative : 1a "conférence de citoyens" sur les organismes génétiquement modifiés'. Revue Française de Science Politique, Volume 50, $\mathrm{n}^{\circ} 4-5: 779-810$.

-Budge, I. (1996) The new challenge of direct democracy. London: Polity Press.

-Dahl, R. A. (1971) 'The City in the Future of Democracy', pp. 85-114 in: Cook, Morgan (eds.), Participatory Democracy. San Francisco: Canfield Press.

-Dahl, R. A., Tufte, E. A. (1974) Size and Democracy. Stanford: Stanford University Press.

-Elias, N. (1991) Qu'est-ce que la sociologie ? French translation of Yamin Hoffmann. La Tour d'Aigues: L'Aube.

-Falise, M. (2003) 'La démocratie participative : promesses et ambiguités'. Paris : éditions de l'Aube.

-Fishkin, J. S. (1995) The Voice of the People, Public Opinion and Democracy. New Haven: Yale University Press.

-Genieys W. (2005) 'The Sociology of Political Elites in France: The End of an Exception? '. International Political Science Review, vol. 26, n4, 413-430.

-Inglehart, R., Baker, W. (2000) 'Modernization, cultural change, and the persistence of traditional values'. American Sociological Review, vol. $65: 19-51$.

-Jouve, B. (2005) 'La démocratie en métropoles : gouvernance, participation et citoyenneté'. Revue française de science politique 55: 317-335.

-Kersting, N. (2005) 'Reforming local electoral systems in Europe', in: H. Reynaert, K. Steyvers, P. Delwit, J.-B. Pilet (Eds.), Revolution or Renovation? Reforming local politics in Europe. Brugge: Vanden Broele, 29-48.

-Kerrouche, E. (2008) L'intercommunalité en France. Paris: Montchrestien.

-Koebel, M. (2006) Le pouvoir local ou la démocratie improbable. Bellecombe-en-Bauges : Le Croquant.

-Larsen, C. A. (2002) 'Municipal Size and Democracy: A Critical Analysis of the Argument of Proximity based on the Case of Denmark'. Scandinavian Political Studies 25 (4): 317-332.

-Le Roy, M. K. (1995) 'Participation, Size, and Democracy: Bridging the Gap between Citizens and the Swedish State'. Comparative Politics 27: 297-316.

-Mabileau, A. (1994) Le système local en France. Paris : Montchrestien.

-Marrel, G. (2004) 'Le Cumul des mandats contre la démocratie locale ? '. Pouvoirs locaux $62: 122-28$.

-Norris, P. (ed.) (1999) Critical Citizens, Global Support for Democratic Government.

Oxford: Oxford University Press.

-Paoletti, M. (1997) La démocratie locale et le référendum. Paris: L'Harmattan.

-Pitkin, H. (1972) The Concept of Representation. Berkeley: University of California Press.

-Premat, C. (2005) 'The Growing Use of Referenda in Local Politics: a Comparison of France and Germany' in: H. Reynaert, K. Steyvers, P. Delwit, J.-B. Pilet (Eds.), Revolution or

Renovation? Reforming local politics in Europe. Brugge: Vanden Broele, 185-212.

-Premat, C. (2006) 'Malentendus sur la démocratie participative, Réflexion sur les primaires socialistes'. Sens Public, http://www.sens-public.org, 5 December 2006.

-Ragin, C. (2004) 'La place de la comparaison: jalons pour la recherche comparative configurationnelle'. Revue Internationale de Politique Comparée, vol. 11, 1: 117-128. -Rancière, J. (1995) La Mésentente. Paris: Galilée.

-Sintomer, Y. (2007) Le pouvoir au peuple: jurys citoyens, tirage au sort et démocratie participative. Paris : La Découverte. 
-Steyvers, K., Pilet J.-B., Reynaert H., Delwit P. (Eds.), 'Introduction', in: H. Reynaert, K. Steyvers, P. Delwit, J.-B. Pilet (Eds.), Revolution or Renovation? Reforming local politics in Europe. Brugge: Vanden Broele, 11-28.

-Taniguchi, M. (2006) 'A Time Machine: New Evidence of Post-Materialist Value Change'. International Political Science Review, vol. 27, 4: 405-425.

-Unger, R. M. (1998) Democracy realized, the progressive alternative. London, New York : Verso.

-Wargny C. (1978) Mairies frappées d'autogestion. Paris : Syros.

-Weale, A. (1999) Democracy. Saint Martin's Press.

- Westerståhl, J. (1981) 'Participation and representation', in: Per Torsvik (ed.), Mobilization Center-Periphery Structures and Nation-Building. Bergen: Universitetsforlaget, 429-450.

-Wolf, M., Osselin, J. (1979), Les ascenseurs de la ZUP, contrôle populaire et autogestion municipale. Paris: Maspero. 